\title{
Person Role Title
}

National Cancer Institute

\section{Source}

National Cancer Institute. Person Role Title. NCI Thesaurus. Code C113644.

An identifying designation assigned to an individual that corresponds with their function. 